\title{
Childhood Blindness
}

\author{
ALLEN FOSTER* \\ London
}

The presentation of a blind child is a relatively uncommon occurrence for most ophthalmologists, however worldwide there are over one million blind children and many more with severe visual impairment. This review considers the patterns of childhood blindness in different parts of the world with particular emphasis on recent findings from Africa.

In discussing childhood blindness certain difficulties must be recognised. First, there is a paucity of data on prevalence and causes of childhood blindness. Secondly, the available data use different definitions of blindness and classifications of the causes of blindness. Thirdly, the method of obtaining the data varies, including blind registrations, community based surveys and examination of children in blind schools. All these factors make comparisons between the available data unsatisfactory. This acknowledged, there is value in attempting to look at the differences in prevalence and causes of blindness in different areas of the world, in order to identify priorities for the prevention of unnecessary blindness in children.

\section{Geographical Variations}

The causes of childhood blindness can be usefully considered according to the classification given in Table I. In Europe and North America, genetic factors are responsible for between $30-50 \%$ of cases, with familial congenital cataract and hereditary retinal diseases being largely responsible. Other important causes result from problems at childbirth and in the perinatal period causing retinopathy of prematurity, and optic atrophy due to hypoxia from brain damage. (Table II.) In the Caribbean and parts of South America, intrauterine infections, particularly rubella, are a major cause of childhood blindness (4). Corneal
Table I Classification of Aetiological Factors in Childhood Blindness

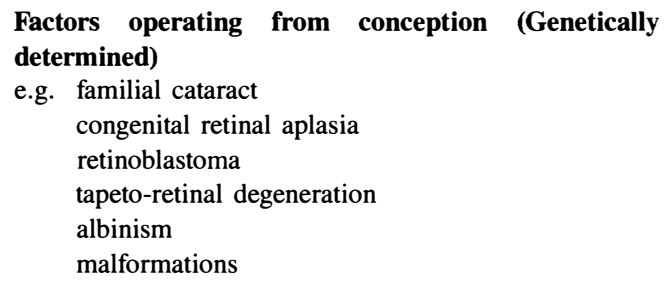

Factors operating during the intra-uterine period

e.g. rubella

toxoplasmosis

syphilis

toxins/drugs

Factors operating at birth or in the immediate perinatal period

e.g. retinopathy of prematurity

hypoxia resulting in damage to the visual pathways

ophthalmia neonatorum

\section{Factors operating in childhood \\ e.g. vitamin A deficiency \\ measles \\ external eye infections \\ trauma \\ meningo/encephalitis}

scarring from malnutrition and ocular infections are responsible for up to $25 \%$ of childhood blindness in Latin America, occurring more frequently in rural areas. The importance of malnutrition in South America may not be reflected in the statistics from blind school surveys, where the children tend to come from the cities in which hereditary factors and intrauterine infections predominate. (Table III.) In the Mediterranean and Middle East, hereditary 
Table II Anatomical cause of Childhood Blindness in Europe and North America by \%

\begin{tabular}{lccc}
\hline Country & USA (l) & Edinburgh (2) & Norway (3) \\
No. of Blind Children & 16 states & $n=99$ & $n=534$ \\
Year & 1970 & 1987 & 1985 \\
\hline Corneal Scar/ & & & \\
$\quad$ Phthisis & 2 & 1 & 0 \\
Cataract & 13 & 12 & 10 \\
Uveitis & 3 & 1 & 0 \\
Retinal disease & 33 & 36 & 42 \\
Optic atrophy & 9 & 16 & 14 \\
Glaucoma & 0 & 2 & 0 \\
Whole eye/others/ & & & \\
$\quad$ Unknown & 40 & 31 & 34 \\
e.g. malformations & & & \\
$\quad$ cortical blindness & & & \\
$\quad$ albinism & & & \\
\hline
\end{tabular}

Table III Anatomical cause of Childhood Blindness in Jamaica, Peru and Bolivia by \%

\begin{tabular}{|c|c|c|c|}
\hline $\begin{array}{l}\text { Country } \\
\text { No. of Blind Children } \\
\text { Year }\end{array}$ & $\begin{array}{c}\text { Jamaica (4) } \\
n=108 \\
1986\end{array}$ & $\begin{array}{c}\text { Peru (5) } \\
n=278 \\
1986\end{array}$ & $\begin{array}{c}\text { Bolivia (6) } \\
n=78 \\
1988\end{array}$ \\
\hline $\begin{array}{l}\text { Corneal Scar/ } \\
\text { Phthisis }\end{array}$ & 5 & 9 & 23 \\
\hline Cataract & 39 & 21 & 21 \\
\hline Uveitis & 5 & 2 & 2 \\
\hline Retinal disease & 15 & 28 & 23 \\
\hline Optic atrophy & 18 & 10 & 10 \\
\hline Glaucoma & 15 & 23 & 10 \\
\hline $\begin{array}{l}\text { Whole eye/others/ } \\
\text { unknown }\end{array}$ & 3 & 7 & 11 \\
\hline Rubella infection & 22 & $?$ & 12 \\
\hline
\end{tabular}

factors, in part due to consanguinity are reported to account for $77 \%$ (Lebanon), $79 \%$ (Cyprus), and 84\% (Saudi Arabia) of childhood blindness. ${ }^{7,8,9}$

This contrasts with large parts of Africa and Asia where nutritional factors, and ocular infections account for more than half of all childhood blindness. ${ }^{10}$ In Asia, diarrhoea is the important predisposing factor for vitamin A deficiency and blindness from corneal scarring, whilst in Africa up to $50 \%$ of childhood blindness is associated with recent measles infection. Figure 1 summarises the geographical variations in the causes of blindness in children.

\section{Prevalence of Childhood Blindness}

The prevalence of childhood blindness in
England calculated from blind registrations between $1969-1976$ is $0.09 / 1000(0-4$ years $)$ and $0.23 / 1000$ (5-15 years) giving a total of approximately 2,300 children registered blind. ${ }^{11}$ In comparison a survey in Bangladesh gave a prevalence of binocular blindness of $0.64 / 1000$ for children aged 0-5 years from rural areas, and 1.09/1000 for children from urban slums. ${ }^{12}$ The best available data in Africa is from a survey of 5,436 children aged 0-5 years in the Lower Shire Valley of Malawi, where the prevalence of bilateral blindness was $1.1 / 1000^{13}-12$ times greater than for England. (Table IV.) However, these figures are likely to underestimate the size of the problem, because at least $50 \%$ of children who become blind in developing countries die within the next 12 months from infections, malnutrition and neglect. ${ }^{12}$

A conservative estimate for Africa would suggest that there are 150,000 blind children aged

\section{CAUSES OF CHILDHOOD BLINDNESS}
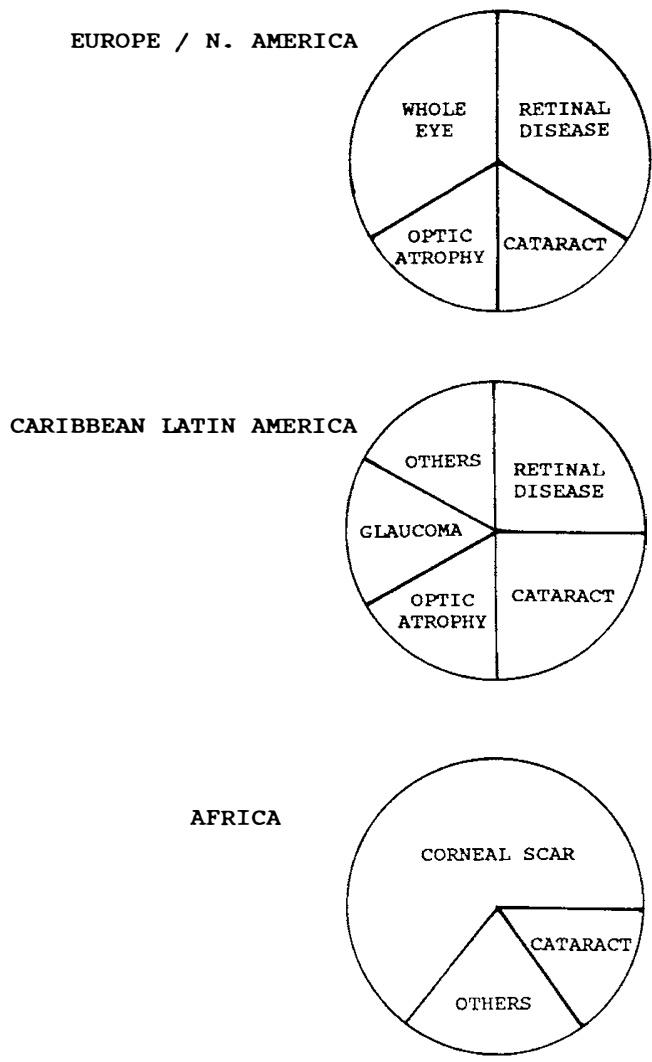

Figure 1 
Table IV Geographical variations in the prevalence and major factors causing Childhood Blindness

\begin{tabular}{|c|c|c|c|}
\hline & Prevalence/1000 children & Major factors & $\begin{array}{l}\text { Estimated No. } \\
\text { of Blind Children } \\
(0-15 \text { years })\end{array}$ \\
\hline $\begin{array}{l}\text { Europe and } \\
\text { North America }\end{array}$ & $\begin{array}{l}0.09 \text { (0-4 years) } \\
0.23 \text { (5-15 years) } \\
\text { (England) }\end{array}$ & $\begin{array}{l}\text { Hereditary. } \\
\text { Problems at birth:- } \\
\text { (particularly pre-term babies) }\end{array}$ & $\begin{array}{l}\text { England }-2,300 \\
\text { USA }-12,000\end{array}$ \\
\hline $\begin{array}{l}\text { Latin America } \\
\text { and Caribbean }\end{array}$ & $?$ & $\begin{array}{l}\text { Intra-uterine infections. } \\
\text { (Nutritional/Measles in } \\
\text { rural areas) }\end{array}$ & $60,000-90,000$ \\
\hline Asia & $\begin{array}{l}0.64 \text { (0-5 years) } \\
\text { (Bangladesh }- \text { rural }) \\
1.09 \text { (0-5 years) } \\
\text { (Bangladesh }- \text { urban })\end{array}$ & Nutritional/Diarrhoea & $400,000-900,000$ \\
\hline Africa & $\begin{array}{l}1.1(0-5 \text { years }) \\
\text { (Malawi) }\end{array}$ & $\begin{array}{l}\text { Nutritional/Measles. } \\
\text { Lack of eye services. }\end{array}$ & $250,000-400,000$ \\
\hline
\end{tabular}

Table V Anatomical cause of Blindness in African Children by \%

\begin{tabular}{|c|c|c|c|c|c|c|c|c|c|c|}
\hline \multirow{3}{*}{$\begin{array}{l}\text { Country } \\
\text { No. of Blind } \\
\text { Children }\end{array}$} & \multicolumn{5}{|c|}{ EAST AFRICA } & \multicolumn{3}{|c|}{ WEST AFRICA - SAHEL } & \multicolumn{2}{|c|}{ WEST AFRICA - COASTAL } \\
\hline & $\begin{array}{c}\text { Kenya } \\
\text { (14) }\end{array}$ & $\begin{array}{c}\text { Ethiopia } \\
\text { (15) }\end{array}$ & $\begin{array}{c}\text { Tanzania } \\
\text { (16) }\end{array}$ & $\begin{array}{c}\text { Malawi } \\
\text { (17) }\end{array}$ & $\begin{array}{l}\text { Tanzania } \\
\text { (18) }\end{array}$ & $\begin{array}{l}\text { Nigeria } \\
\text { (north) }\end{array}$ & Mali & $\begin{array}{c}\text { Ghana } \\
\text { (north-west) }\end{array}$ & $\begin{array}{c}\text { Togo } \\
\text { (south) }\end{array}$ & $\begin{array}{c}\text { Nigeria } \\
\text { (south-west) }\end{array}$ \\
\hline & 749 & 195 & 426 & 270 & 72 & $\begin{array}{l}(19) \\
104\end{array}$ & $\begin{array}{l}(20) \\
73\end{array}$ & $\begin{array}{c}(21) \\
65\end{array}$ & $\begin{array}{l}(22) \\
54\end{array}$ & $\begin{array}{l}(23) \\
140\end{array}$ \\
\hline $\begin{array}{l}\text { Corneal Scar/ } \\
\text { Phthisis }\end{array}$ & 49 & 72 & 71 & 75 & 67 & 69 & 45 & 63 & 43 & 22 \\
\hline Cataract & 10 & 6 & 7 & 3 & 18 & 3 & 5 & 5 & 9 & 19 \\
\hline Uveitis & 5 & 4 & 5 & 0 & 0 & 5 & 14 & 6 & 6 & 5 \\
\hline Retinal disease & 2 & 3 & 4 & 1 & 4 & 11 & 6 & 10 & 9 & 11 \\
\hline Optic atrophy & 11 & 10 & 4 & 3 & 3 & 5 & 6 & 5 & 6 & 14 \\
\hline Glaucoma & 0 & 0 & 1 & 0 & 1 & 4 & 9 & 8 & 16 & 14 \\
\hline $\begin{array}{l}\text { Whole eye/othe } \\
\text { /unknown }\end{array}$ & 23 & 5 & 8 & 18 & 7 & 3 & 15 & 3 & 11 & 15 \\
\hline $\begin{array}{l}\text { \% Ass. with } \\
\text { Measles infec }\end{array}$ & $\begin{array}{r}31 \\
\text { tion }\end{array}$ & 27 & 37 & 44 & $?$ & 29 & $?$ & 52 & 25 & 14 \\
\hline
\end{tabular}

0-5 years and a similar figure aged 6-15 years, giving a total of at least 300,000 blind children, with 50,000 - 80,000 new cases per year, many of whom die. Bangladesh with a total population of 94 million is estimated to have 30,000 children blinded each year of which 15,000 survive totally blind, and a further 45,000 survive with appreciable visual impairment from corneal damage or lens opacity. ${ }^{12}$

\section{Childhood Blindness in Africa}

Table V summarises the data on the anatomical cause of childhood blindness from 49 blind schools and 2 hospitals in sub-Saharan African countries.

\section{(a) Regional Variations}

Bilateral corneal scarring or phthisis bulbi is responsible for $49-75 \%$ of childhood blindness in East Africa, $45-69 \%$ in the Sahel area of West Africa and $22-43 \%$ on the coastal area of West Africa, but only $1-2 \%$ of childhood blindness in Europe, 5\% in Jamaica and 9-23\% in Latin America. Measles infection is associated with $27-44 \%$ of childhood blindness in East Africa, $29-52 \%$ in the Sahel and $14-25 \%$ in the coastal areas of West Africa. The dietary use of red palm oil, rich in vitamin $A$, in the coastal (rain forest) areas of West Africa results in less corneal blindness from xerophthalmia and associated measles infection compared 
with East Africa and the Sahel area of West Africa.

The other important causes of blindness in African children are congenital cataract (3-19\%), uveitis $(0-14 \%)$, retinal disease $(1-11 \%)$, optic atrophy $(3-14 \%)$ and glaucoma $(0-16 \%)$. It is interesting to note that congenital/juvenile glaucoma only accounted for $1 \%$ of blindness in East Africa, but $4-16 \%$ in West Africa. This would appear to be a true regional difference, but the reasons for it are not clear.

There has been considerable discussion on the relative importance of vitamin A deficiency, ${ }^{14,24,25,26,27,28,29}$ measles $^{30}$ and herpes simplex virus ${ }^{19,31}$ in causing corneal ulceration, scarring and resultant blindness in different parts of Africa. The importance of these conditions varies from place to place, and from time to time depending on famine, measles epidemics and the availability of eye services. The inter-relationship of different factors is important in planning any programme to reduce the amount of avoidable childhood blindness in Africa.

\section{(b) Measles associated corneal ulceration}

Measles infection is usually accompanied by photophobia, lacrimation and a superficial punctate kerato-conjunctivitis which lasts 2-10 days. In Africa $1-4 \%$ of hospitalised children with measles develop true corneal ulceration as distinct from punctate keratitis, and the ulceration is bilateral in at least $50 \%$ of cases (32). In a study from Tanzania measles infection was associated with $69 \%$ of corneal ulcers which subsequently resulted in bilateral blindness. ${ }^{32}$ This confirms the finding from blind school surveys given in Table $\mathrm{V}$ where measles is associated with one quarter to one half of all childhood blindness and $50-80 \%$ of corneal blindness in children.

The pathways by which measles leads to corneal ulceration are complex. First the measles virus may cause a superficial confluent keratitis, particularly in the exposed area of the cornea, which can lead to a central epithelial ulcer. This occurs especially in dehydrated children, lying with exposed corneas. Second, measles causes fever and a depression of cellmediated immunity. Both these factors may predispose to herpes simplex infection. Herpetic stomatitis is common following measles infection in African children ${ }^{19,31}$ and herpes

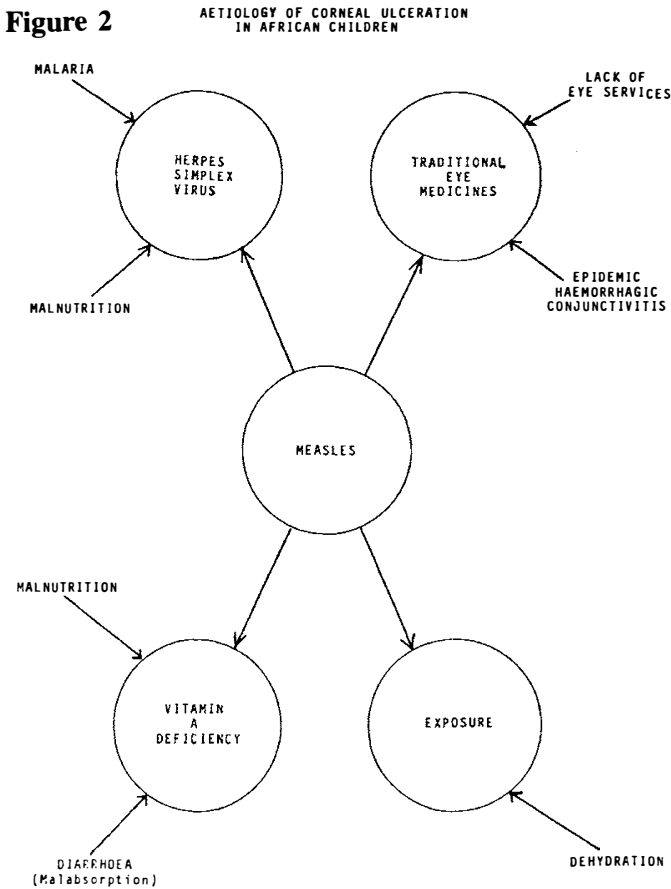

simplex keratitis was responsible for $20 \%$ of measles associated corneal ulcers in the Tanzanian study. ${ }^{32}$ Third, measles conjunctivitis, causing red eyes together with the local knowledge that measles can result in blindness leads mothers to use Traditional Eye Medicines (TEM) in an effort to help their children. Many of these TEM are harmless, but occasionally they may lead to corneal ulceration and blindness. Lastly, measles produces anorexia and gastroenteritis resulting in a decrease in supply of vitamin A and protein to a child who may already have marginal liver reserves of vitamin A. At the same time the increase in demand for vitamin $\mathrm{A}$ associated with measles infection results in a sudden decompensation in vitamin A metabolism. The ocular manifestation of this deficiency is necrosis of the corneal stroma, often in both eyes and in severe cases from limbus to limbus (keratomalacia). This bilateral, deep and perforating corneal ulceration is responsible for most of the blindness in African children.

Figure 2 summarises the pathways by which measles may lead to corneal ulceration. Ulceration due to herpes simplex virus or measles keratitis/exposure is usually unilateral and superficial, and therefore rarely causes 


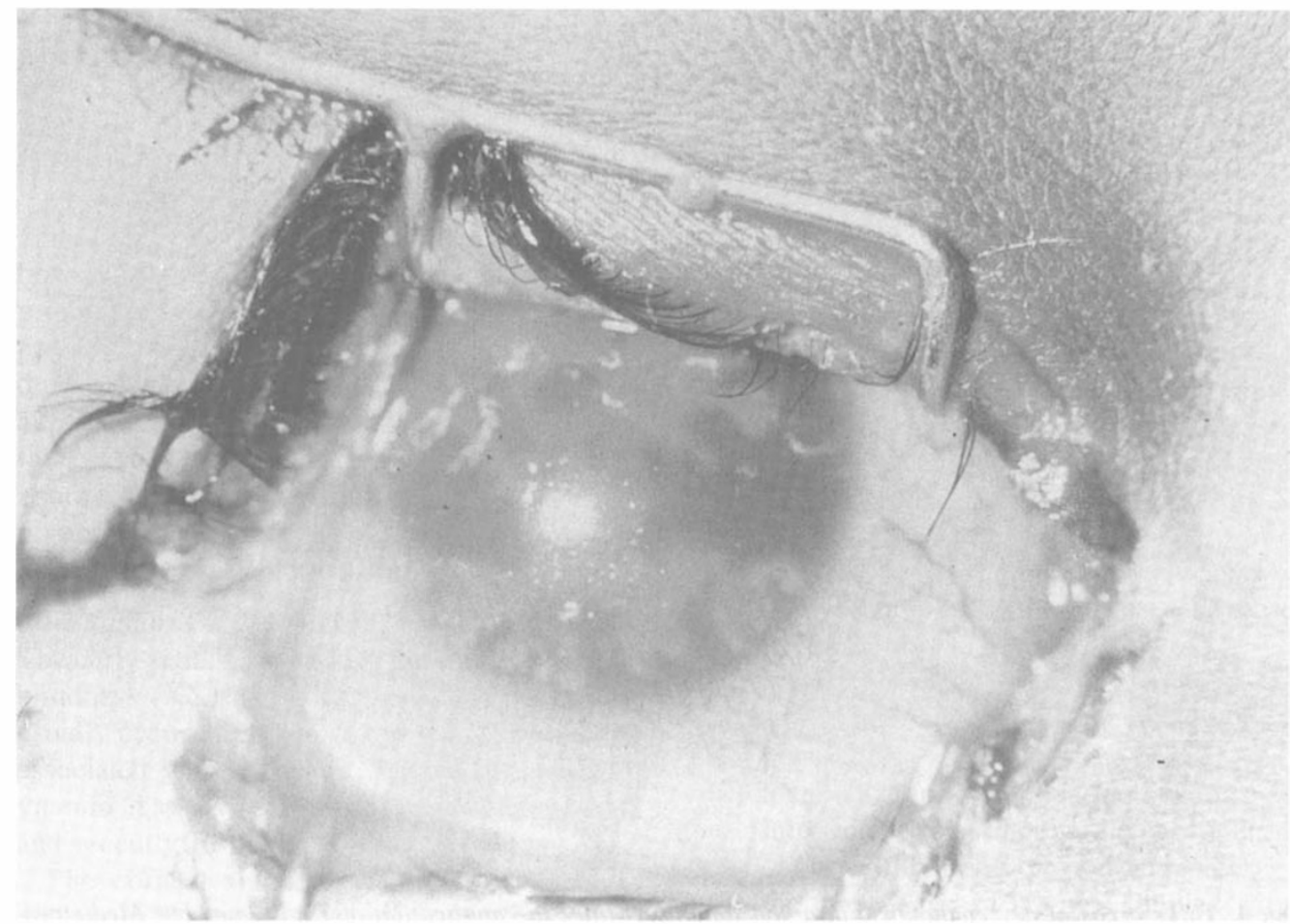

Fig. 3. Amoeboid herpetic ulcer in a young Tanzanian child with measles.

childhood blindness. However, TEM and vitamin A deficiency cause bilateral and deep ulcers which are responsible for the majority of corneal blindness.

\section{(c) Herpes Simplex Keratitis}

Corneal ulceration due to herpes simplex virus has been well documented in Africa. ${ }^{19,32}$ The ulceration is more commonly geographic/ amoeboid than dendritic, bilateral in a quarter of cases and often occurring before the age of 2 years. (Figure 3.) These features are atypical of herpetic keratitis in Western countries. Besides measles other predisposing factors for herpetic keratitis in African children are malnutrition (particularly marasmus) and malaria. Clusters of patients with herpetic ulcers have been noted to occur towards the end of the rainy season when malaria is at its worst, and also occasionally in association with epidemics of meningococcal meningitis.

In areas where ophthalmic services are sparse, the diagnosis of herpetic ulcer is often missed and many of these children develop chronic ulcers which result in quite severe superficial corneal scarring with visual loss. Fortunately this is usually unilateral. Once the diagnosis is made, treatment with topical antivirals is usually effective in healing the ulcer. In many areas of rural Africa antivirals are not readily available, but it is possible to make idoxuridine drops relatively simply from the gallenical powder.

\section{(d) Traditional Eye Medicines}

Traditional eye medicines come in many forms including herbal medicines, lime juice, urine, toothpaste, kerosene and breast milk to mention but a few. Many are harmless and some may be beneficial, however corneal ulceration may be caused by the caustic, physical or thermal trauma of the TEM, or by secondary infection with fungi (from plant materials) or bacteria, particularly Neisseria gonococcus (from urine).

Measles is the major predisposing factor for corneal ulceration due to TEM in children. Other factors which lead to clusters of these ulcers in children or adults are epidemics of viral haemorrhagic conjunctivitis, lack of eye services and the particular practices of individual traditional healers. 


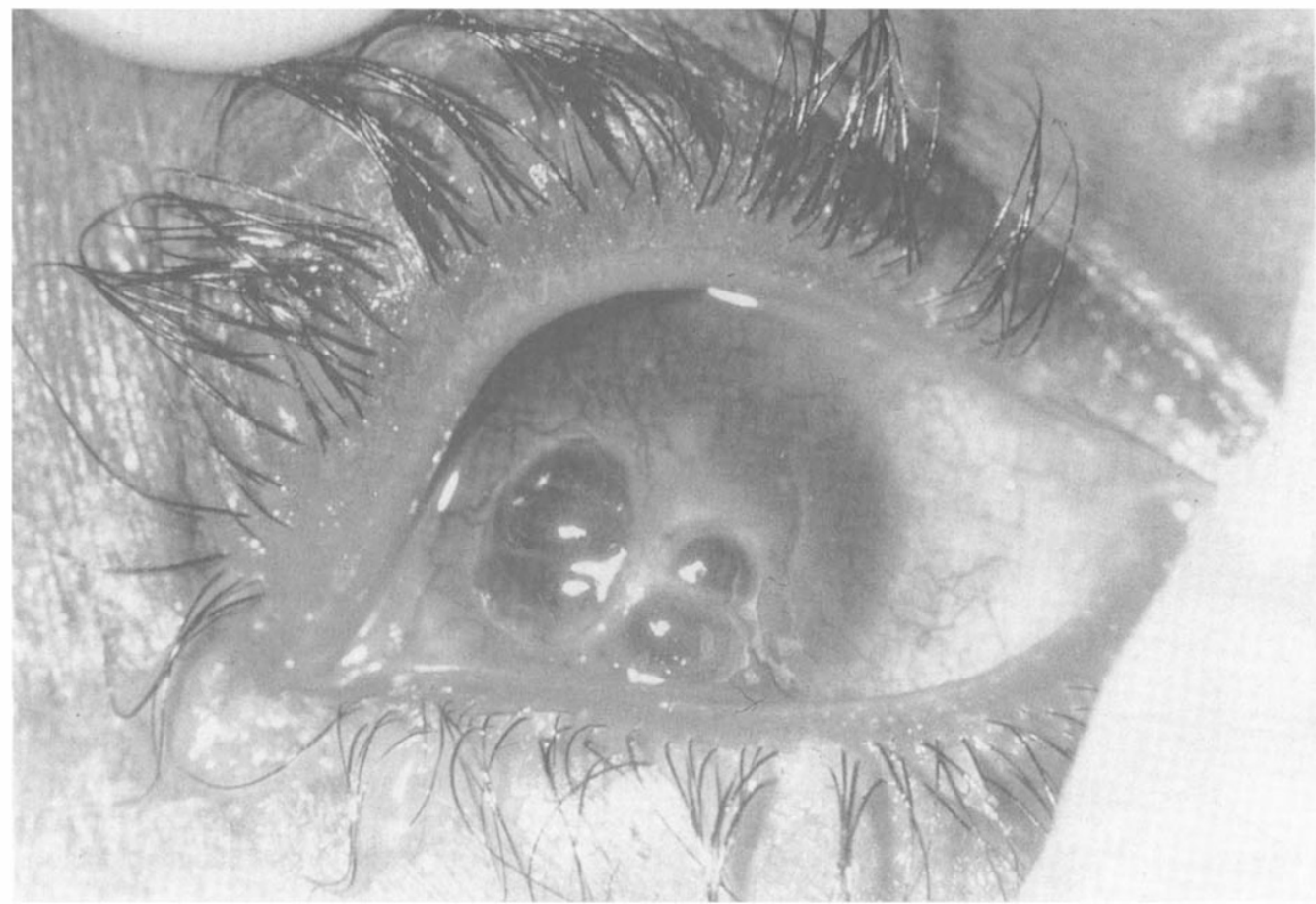

Fig. 4. Three areas of descematocoele in a Tanzanian girl after the application of Traditional Eye Medicines.

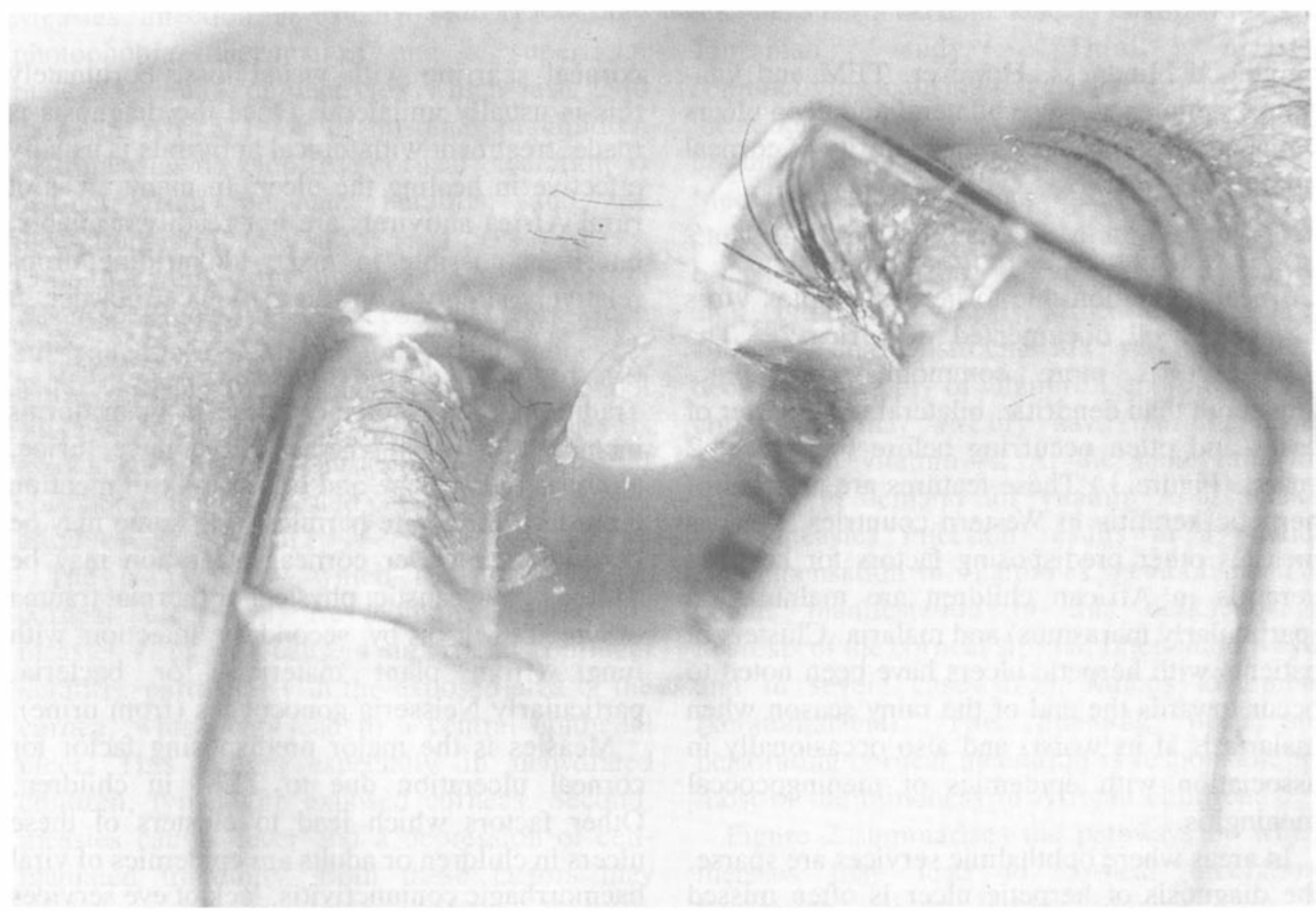

Fig. 5. Stromal necrosis with descematocoele formation in a Tanzanian child with measles associated corneal ulceration due to vitamin A deficiency. 
The diagnosis of corneal ulceration due to TEM is based upon a positive history (which may be very difficult to illicit), together with the presence of chemical conjunctivitis and atypical corneal ulcers (Figure 4).

Treatment of the ulcers is often unrewarding unless there is a secondary infection which can be treated with antibiotics or antifungals. Health promotion, to inform the public through radio or press, about the danger of TEM particularly during epidemics of conjunctivitis can help, but alternative eye care must be provided at the same time. Most traditional healers if correctly approached are very willing to use antibiotic eye ointments instead of TEM, if the ointment is made freely available to them.

\section{(e) Vitamin A Deficiency}

The early signs of vitamin A deficiency are night blindness (XN) and Bitot spots (X1B). ${ }^{33}$ These usually occur after the age of three years and are associated with a chronic dietary deficiency of vitamin $\mathrm{A}$ as is seen in Indonesia, Bangladesh and recently Ethiopia. $33,12,34$

The corneal signs of vitamin A deficiency, xerosis (X2) and corneal ulcer (X3), occur in children with Malnutrition, Malabsorption (chronic diarrhoea) or Measles, and are most commonly seen between the ages of one and four years. The ulcers are sometimes epithelial and may be due to an area of dry keratinised corneal epithelium being denuded. More commonly however the morphology is a well-demarcated round or oval area of full thickness stromal necrosis often with intact epithelium (Figure 5). The response to therapy if diagnosed early is dramatic, with healing of the ulcer in 4-5 days, leaving a residual corneal scar.

The mortality in children with frank keratomalacia is high, exceeding $30 \%$ even with treatment. ${ }^{32}$ Recent work from Indonesia and Tanzania now suggests that vitamin A deficiency, even sub-clinical, is responsible for an increased risk of respiratory and diarrhoea infections in children. ${ }^{35}$ Vitamin A administration to children with measles in developing countries is now recommended by WHO and UNICEF, in order to reduce child mortality and childhood blindness. ${ }^{36,37}$

\section{(f) Other causes of corneal ulceration}

Trauma, bacterial infection, exposure from proptosis and particularly ophthalmia neonatorum are the other causes of childhood ulceration in Africa. Ophthalmia neonatorum due to Neisseria Gonococcus is relatively common in some parts and is estimated to account for $2-5 \%$ of childhood blindness. ${ }^{32}$ Penicillinase producing Neisseria is becoming an increasing problem in many African urban situations.

In summary, childhood blindness in Africa, is mainly due to corneal ulceration from vitamin A deficiency, traditional eye medicines and herpes simplex keratitis, all of which are associated with measles infection. The other significant cause of bilateral corneal ulceration is ophthalmia neonatorum.

The relative importance of each cause of corneal ulceration in different parts of Africa will depend on:

(1) the prevalence of vitamin A deficiency and undernutrition in the childhood population.

(2) local practices in relation to measles infection - for example, the use of TEM, or the withholding of food and water.

(3) the prevalence of herpes simplex virus infection in children and their mothers.

These factors will vary in time and place according to the availability of food, eye services, and seasonal variations in infectious diseases.

\section{Prevention and Treatment}

\section{(a) Measles immunisation}

$25 \%-50 \%$ of all childhood blindness in Africa is associated with measles. Immunisation at the age of nine months as recommended by most African countries would do much to reduce child mortality and childhood blindness. Herd immunity can be expected when immunisation cover reaches $80 \%$, but this figure is rarely attained in many African countries, partly due to lack of public awareness, cost and the logistics of the immunisation programme, particularly maintaining the cold chain. The Expanded Programme of Immunisation (EPI of World Health Organisation) is now extending the coverage of immunisation and it is to be hoped that there will be a consequent reduction in mortality and morbidity from blindness.

(b) Improve vitamin A status in pre-school children

There are three possible ways of improving the 
vitamin A dietary intake of young children:

(1) Education programme to make mothers and girls more aware of the importance of readily available foods rich in vitamin $\mathrm{A}$, e.g. dark green leafy vegetables, mangoes, papaya and red palm oil.

(2) Distribution of vitamin A capsules (200,000 I.U.), once every 4-6 months to either, all pre-school children or to only those at high risk of developing xerophthalmia e.g. children with malnutrition, chronic diarrhoea, measles or early signs of vitamin A deficiency. This has been tried in some countries with a limited amount of success. ${ }^{12}$

(3) Fortify with vitamin A a centrally processed food which is generally available and consumed by pre-school children. Sugar would be most suitable, however the cost of such a programme is considerable in terms of the resources spent on health in many African countries.

All these programmes require political determination, good administration and adequate infrastructure to achieve success. The nutrition education programme would have a long-lasting effect and is the most cost-effective approach, but probably needs to be implemented together with a short-term strategy e.g. distribution of vitamin A capsules to children at high risk.

(c) Ready availability of antibiotic eye ointment The majority of African people live in rural areas where eye services are inadequate and eye infections (epidemic conjunctivitis, trachoma, ophthalmia neonatorum, and measles) are common. Traditional Eye Medicines (herbal medicines) or Inappropriate Eye Therapies (kerosene, sugar water, antibiotic powders or steroid drops) are commonly used topically to treat these eye infections either by traditional healers or by self-administration. The ready availability to rural people of an inexpensive, but effective topical antibiotic (e.g. enriched tetracycline ointment $1 \%$ ) could do much to reduce blindness from corneal ulcers in children and adults.

(d) Management of corneal ulceration in African children

The following prevention and treatment schedules are suggested for areas of Africa where corneal ulceration and corneal scarring in children occur, or where protein-energy malnutrition is a problem.

Prophylactic administration of vitamin A, 200,000 IU orally, as a single dose should be given to children with:

- marasmus or kwashiorkor;

- chronic diarrhoea;

- severe measles;

- night blindness, or Bitot's spots.

If a child is seen with a suspected corneal ulcer, then the following treatment is recommended:

(1) Immediate administration of vitamin $\mathrm{A}$, 200,000 IU orally (or injection of aqueous vitamin A, 100,000 IU, if the child is vomiting); repeat after one day and again after one week. (Half the dose for children under one year of age.)

(2) Antibiotic eye ointment (e.g. $1 \%$ tetracycline) three times per day.

(3) Atropine eye ointment $0.5 \%$, once daily.

(4) An eye pad.

(5) General treatment for malnutrition, diarrhoea and other systemic infections.

If the corneal ulcer fails to improve within five days on this regimen, it may indicate infection with herpes virus. This will require additional treatment with anti-virals, or possibly mechanical debridement of the corneal epithelium, if the ulcer is still superficial.

It is very important for all health workers in Africa to be on the lookout for the early development of corneal ulceration in any child with malnutrition or measles; failure by the child to open its eyes may be indicative of corneal ulceration.

\section{(e) Management of childhood cataract}

Cataract in children, due either to hereditary factors, rubella or other causes accounts for $10-13 \%$ of blind registrations in industrialised countries (Table II), $21-39 \%$ in Latin America and the Caribbean (Table III), and $3-19 \%$ in Africa (Table V).

In Africa it is not uncommon to find schoolage children and even adolescents in blind schools with bilateral mature untreated cataracts, or the complications of unsuccessful surgery. In one school eight of 14 aphakic eyes had blinding surgical complications. ${ }^{15}$

The early recognition, surgical treatment and 
management of aphakia in children is one priority in the reduction of childhood blindness. This requires training of all medical workers in the recognition of cataract and the development of tertiary eye centres in which there are experienced ophthalmologists and appropriate facilities for the treatment of congenital cataract.

\section{Conclusion}

In countries with sophisticated medical care services, hereditary causes and factors operating at the time of birth (e.g. hypoxia) are responsible for the majority of cases of childhood blindness. Better neonatal care of pre-term babies has reduced neonatal mortality, but resulted in an increase in morbidity including visual handicap. Genetic counselling and further improvements in the management of pre-term infants could result in a reduction in childhood blindness in Europe and North America.

In areas of the world with intermediate medical services, intra-uterine infections, particularly rubella, remain an important preventable cause of childhood blindness. Immunisation of infants with the combined measles-rubella vaccine would reduce the number of children born with the congenital rubella syndrome.

In the large rural and urban slum areas of Asia, Africa and parts of South America, vitamin A deficiency, measles and the lack of eye care services are responsible for $50-75 \%$ of blindness in children. The available data suggests that there are approximately one million blind children in the world, of which $90 \%$ live in third world countries. At least half and probably three-quarters of childhood blindness could be prevented if children received an adequate intake of vitamin $\mathrm{A}$, were immunised against measles and rubella, and had ready access to an antibiotic eye ointment.

\section{References}

${ }^{1}$ Kahn HA, Moorhead HB. Statistics on Blindness in the Model Reporting Area, 1969-1970. No NIH 73-427 - Washington, US Govt Printing Office 1973.

${ }^{2}$ Philips CI, Levy, AM, Newton M, Stokoe LN. Blindness in schoolchildren: importance of hereditary, congenital cataract and prematurity. Br J Ophthalmol 1987, 71: 578-84.

${ }^{3}$ The Norwegian Registry of Blindness Records 1985.
${ }^{4}$ Moriarty B. Childhood Blindness in Jamaica. $B r J$ Ophthalmol 1988, 72: 65-7.

${ }^{5}$ Wong L. Personal communication. St. Francisco Blind School. Lima.

.6 Personal Observation in Santa Cruz and Sucre Aprecia Blind Schools.

${ }^{7}$ Merin S, Lapithis AG, Horovitz D. et al: Childhood blindness in Cyprus. Am J Ophthalmol 1972, 74: 538-42.

8 Baghdassarian SA, Tabbara KF. Childhood blindness in Lebanon. Am J Ophthamol 1975, 79: 827-30.

9 Tabbara KF, Badr IA. Changing patterns of childhood blindness in Saudi Arabia. $\mathrm{Br} J$ Ophthamol 1985, 69: 312-15.

${ }^{10}$ Foster A, Sommer A. Childhood Blindness and Corneal Ulceration in Africa. WHO 1986, 64: (5): 619-23. 23: 246-9.

${ }^{11}$ Cullinan T. Epidemiology of Blindness in Clinical Ophthalmology. Ed Miller, Sir S Wright Publ.

${ }^{12}$ Cohen N, Rahman H, Sprague J, Jahl M, Leembuis E, Mitra M. Prevalence and determinants of nutritional blindness in Bangladeshi children. World Health Statistics Quarterly. 1985, 38: 317-29.

13 Chirambo MC. et al. Blindness and visual impairment in southern Malawi. WHO Bull 1986, 64: $567-72$.

${ }^{14}$ Sauter JJ. Xerophthalmia and measles in Kenya. Groningen: Van Denderen 1976.

${ }^{15}$ Personal Observation Sebeta blind school 1986.

${ }^{16}$ Sauter, JJ. Causes of Blindness in 19 schools for blind in Tanzania. Final report for Ministry of Health, Dar-es-Salaam 1978.

${ }^{17}$ Chirambo MC. Causes of blindness among students in blind school institutions in a developing country. Br J Ophthalmol 1976, 60: 655-68.

18 Foster A. "Patterns of Blindness" in Clinical Ophthalmology, Vol. 5, Harper \& Row. Chap 53 Ed Duane 1984.

${ }^{19}$ Sandford-Smith JH, Whittle HC. Corneal ulceration following measles in Nigerian children. $\mathrm{Br} \mathrm{J}$ Ophthalmol 1979, 63: 720-4.

20 Personal Observation, UMAV blind school, Bamako 1987.

${ }^{21}$ Verrey JD. Personal Communication, Wa Blind School 1987.

${ }^{22}$ Personal Observation, Kpalime and Togoville blind school 1987.

${ }^{23}$ Olurin O. Aetiology of Blindness in Nigerian Children. Am J Ophthalmol 1970, 70: 533-40.

${ }^{24}$ Thomson IG. Eye diseases and blindness in relation to vitamin A deficiency in northern Nigeria. $J$ Trop Med Hyg 1956, 59: 115-16.

${ }^{25}$ McLaren DS. Nutrition and eye disease in East Africa: experience in Lake and Central 
Provinces, Tanganyika. J Trop Med Hyg 1960 101-22.

${ }^{26}$ Awdry PN, Cobb B, Adams PCG. Blindness in the Luapula Valley. Centr Afr J Med 1967, 13: 197-201.

27 Cobb B, Awdry PN. Xerophthalmia. Trans Ophthalmol Soc UK. 1968, 88: 579-85.

${ }^{28}$ Franken S. Measles and xerophthalmia in East Africa. Trop Geogr Med 1974, 26: 39-44.

${ }^{29}$ Oomen JMV. Xerophthalmia in Northern Nigeria. Trop Geogr Med 1971.

${ }^{30}$ Dekkers NWHM. The cornea in measles. The Hague: Junk 1981.

${ }^{31}$ Whittle HC, Sandford-Smith J, Kogbe OI, Dosseter J, Duggan M. Severe ulcerative herpes of the mouth and eye following measles. Trans $R$ Soc Trop Med Hyg 1979, 72: 66-9.
${ }^{32}$ Foster A, Sommer A. Corneal ulceration, measles and childhood blindness in Tanzania. $\mathrm{Br} J$ Ophthamol 1987, 71: 331-42.

33 Sommer A. Nutritional Blindness. New York. Oxford Univ Press 1982.

${ }^{34}$ Sheffield V. Report on Vitamin A supplementation programme Ethiopia. Helen Keller International, New York 1985.

${ }^{35}$ Sommer A, Katz J, Tarwotjo I. Increased risk of respiratory disease and diarrhoea in children with pre-existing mild vitamin A deficiency. Am J Clin Nut 1984, 40: 977-86.

36 Barclay A, Foster A, Sommer A. Vitamin A supplements and mortality related to measles: a randomised clinical trial. $\mathrm{Br}$ Med J 1987, 294-96.

${ }^{37}$ Editorial: Vitamin A for Measles. Lancet. 1987, 1067-8. 